\title{
Preliminary investigation on the interaction between some physiological processes in donors and acceptors of assimilates
}

\author{
Z. STARCK
}

Agricultural Academy of Warsaw, Department of Plant Biology

(Received: July 8, 1972)

\begin{abstract}
The interaction between physiological processes in donors and acceptors of ${ }^{14} \mathrm{C}$-assimilates was studied in sunflower and bean plants with temporarily limited supply of assimilates (shading a few days and then replacing in natural light conditions (NL)).

An extended period of shading ( $4-7$ days) affected growth of plants and reduced photosynthetic activity, especially in sunflower. The proportion of ${ }^{14} \mathrm{C}$-transported to roots decreased and that to the stem increased as an effect of preshading and did not significantly change in plants replaced in natural light conditions a few days before ${ }^{14} \mathrm{CO}_{2}$-exposure.

In preshaded blades and roots the rate of dark respiration decreased, but soon improved after a few days of NL conditions following the shading period.

Absorption of ${ }^{32} \mathrm{P}$ coincided with root respiration and sugar content in bean plant, in contrast to sunflower where ${ }^{32} \mathrm{P}$-absorption, calculated per $1 \mathrm{~g}$ of root dry matter in preshaded plants exceeded that in control ones.
\end{abstract}

\section{INTRODUCTION}

Complex source-sink relations involving, among others, photosynthesis, growth and storage processes have been the subject of extensive physiological research but a causal relationship was as yet not established (Crafts, 1970, Milthorpe 1969, Neales et al., 1968). Roots affect the photosynthetic activity probably as an acceptor of photosynthates and donor of mineral nutrition, water, specific hormonal substances and others. A similar complex interaction seems to exist between the processess of organ initiation, extension growth of young organs and photosynthesis (B r a u er, 1970, J es ke, 1971, 1972). The question arises how does the metabolic rate in acceptors determine 
firstly the rate of assimilation and secondly the transport of photosynthates from their donors (G e ig e r, 1966, 1971) and conversely, how does photosynthesis modify growth and distribution of organic substances.

These relationships were investigated by many authors both under natural conditions and when the supply of assimilates was the limiting factor, increasing competition between acceptors.

The present paper, reports some relations between the rate of some physiological processes in donors of assimilates and acceptors, modified by temporary shading which limits the supply of assimilates in young sunflower and bean plants.

All acceptors compared (roots, stem, apical part with developing leaves) were of sink type, in which assimilates not accumulated but metabolized during growth processes. A part of the experimental date was communicated at the Symphosium: "Structure and function of primary root tissues" (S t a r c k, in press).

\section{MATERIALS AND METHODS}

Sunflower and bean plants were grown in water culture out of doors, in the nutrient solution described in previous papers. Some experimental series were shaded with chese-cloth which transmitted about 50 percent of natural daylight (denoted in figures by $s$ ) for a few days and some were replaced for a few days — in natural light conditions (NL). Assimilation experiments were carried out, in the morning, under natural daylight in an atmosphere labelled with ${ }^{14} \mathrm{CO}_{2}$ in a plexiglass chamber. Whole plants were placed inside, but only blades (bean plant) or leaves with apical part (sunflower) were allowed to assimilate ${ }^{14} \mathrm{CO}_{2}$ (Table 1).

Table 1

Conditions during ${ }^{14} \mathrm{CO}_{2}$ and ${ }^{32} \mathrm{P}$ exposure

\begin{tabular}{|c|c|c|c|c|c|c|c|c|c|c|}
\hline \multirow{3}{*}{$\begin{array}{c}\text { Expt. } \\
\text { No }\end{array}$} & \multirow{3}{*}{ Species } & \multirow{3}{*}{$\begin{array}{l}\text { Age of } \\
\text { plants } \\
\text { (days) }\end{array}$} & \multirow{2}{*}{\multicolumn{2}{|c|}{$\begin{array}{c}\text { Conditions of } \\
{ }^{32} \mathrm{P} \text { absorp- } \\
\text { tion }\end{array}$}} & \multicolumn{4}{|c|}{ Conditions of } & \multirow{2}{*}{\multicolumn{2}{|c|}{$\mathrm{CO}_{2}$}} \\
\hline & & & & & \multicolumn{2}{|c|}{${ }^{14} \mathrm{CO}_{2}$ exposure } & \multicolumn{2}{|c|}{$\begin{array}{c}\text { 14C-transloca- } \\
\text { tion }\end{array}$} & & \\
\hline & & & time & ${ }^{\circ} \mathrm{C}$ & time & ${ }^{\circ} \mathrm{C}$ & time & ${ }^{\circ} \mathrm{C}$ & $\% \mathrm{v} / \mathrm{v}$ & sp. rad. \\
\hline Ia & $\begin{array}{l}\text { Bean } \\
\text { plant }\end{array}$ & 20 & $3 \mathrm{hrs}$ & $17-20$ & 60 & $17-22$ & $2 \mathrm{hrs}$ & about 17 & 0,10 & 1.82 \\
\hline IIa & & 20 & $3 \mathrm{hrs}$ & $23-27$ & 40 & $30-35$ & $2 \mathrm{hrs}$ & $28-30$ & 0,19 & 1.05 \\
\hline $\mathrm{Ib}$ & $\begin{array}{l}\text { Sunflo- } \\
\text { wer }\end{array}$ & 23 & $2 \mathrm{hrs}$ & $30-35$ & 45 & $26-31$ & $2 \mathrm{hrs}$ & $28-33$ & 0,10 & 1.38 \\
\hline $\mathrm{IIb}$ & & 24 & 3 hrs & $28-32$ & 30 & $30-35$ & $2 \mathrm{hrs}$ & about 30 & 0,07 & 1.90 \\
\hline
\end{tabular}


Translocation of ${ }^{14} \mathrm{C}$, following $30-60 \mathrm{~min}$. exposure, takes place in natural atmosphere and under natural daylight. After $2 \mathrm{hrs}$ (from the beginning of ${ }^{14} \mathrm{CO}_{2}$-exposure), plants were collected frozen in dry ice, cut into particular organs and storaged at $-15^{\circ} \mathrm{C}$. Total radioactivity of plant material and of the particular fractions (soluble in $80 \%$ ethanol, called supernatant and sugar fraction isolated from ethanol soluble fraction by the use of ion exchangers) were estimated by means of a thin-end window G-M counter. Radioactivity of the insoluble fraction was calculated as the differences between total and that of the soluble fraction. Sugar content was estimated by the anthrone method. Radioactivity of ionizing fraction was calculated as the differences beween supernatant radioactivity and that of sugar fraction (see Starck 1964, 1969). The rate of respiration (oxygen absorption) was measured by Warburg's method. Absorption of ${ }^{32} \mathrm{P}$ by roots was measured for $2-3 \mathrm{hrs}$ and radioactivity was estimated with a liquid Geiger counter (VA-Z 110) after digestion of the plant material in a mixture of perchloric acid, nitric acid and sulphuric acid. All experiments were made in May and June in two succesive years, in 3 replications (two plants in each) except dry matter estimation (including 3 replications, with 5 plants in each).

\section{RESULTS}

Physiological characteristic of ${ }^{14} \mathrm{C}$-donors

The contribution of blades to the total dry matter of the whole plant was about 45 percent in bean plants and about 35 percent in sunflower; the apical part which was also labelled with ${ }^{14} \mathrm{C}$ in sunflower contributed about 10 percent to the total dry matter of the whole plant (data not presented). The apical part with young expanding leaves forms in both species a major apical acceptor for upward moving assimilates. In sunflower (S tarck 1964) transport of ${ }^{14} \mathrm{C}$-assimilates to the apical part exceeded that to the roots in spite of their much higher weight. Also in Shiroya's work (1968) young sunflower seedlings exported upward a high proportion of photosynthates. Therefore it may be supposed that the apical part of sunflower, despite of ${ }^{14} \mathrm{CO}_{2}$ assimilation in situ, did not export labelled photosynthates to the other plant organs, but was an active acceptor.

Shading of the bean plants for a few days caused reduction of blade dry matter but affected only slightly their surface area (Table 2). In sunflower from suboptimal light conditions, both blade dry matter and surface area were greatly reduced. The size of blades immediately after shading or few days after replacing the plants in NL conditions was mostly the same. 


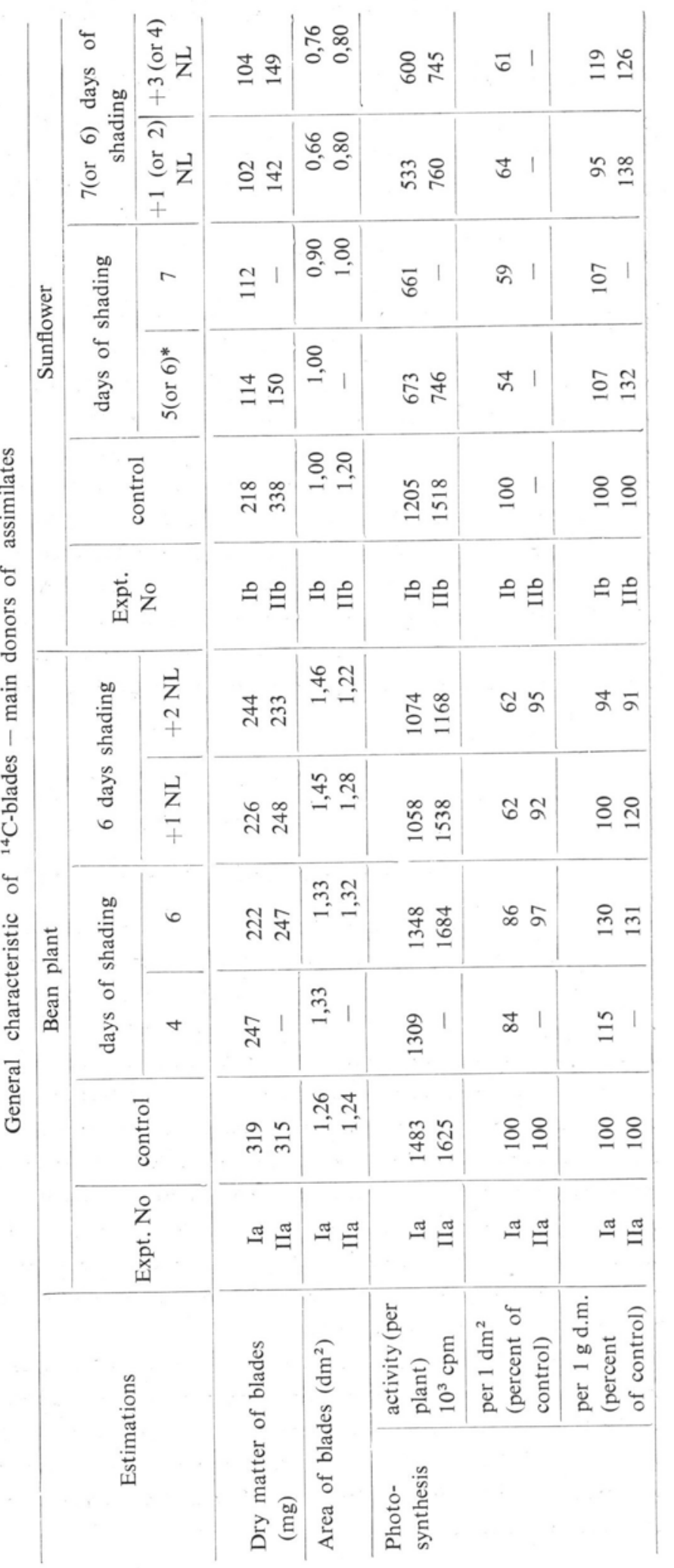




\begin{tabular}{|c|c|c|c|c|c|}
\hline$\stackrel{\pi}{\circ}$ & $\begin{array}{l}n=n \\
n^{n}\end{array}$ & \pm 8 & Bิ & $\approx \mathscr{0}$ & \\
\hline $\bar{m} \approx$ & $\vec{m}=$ & $\approx d$ & to & $\approx 8$ & \\
\hline \& 1 & $m^{2} 1$ & I I & nू 1 & $\infty \begin{array}{l}\infty \\
0\end{array}$ & \\
\hline 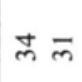 & $7^{2}=0$ & $\mathscr{0}$ & in & $\stackrel{\circ}{\circ}$ & \\
\hline DN & 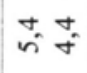 & $\div 5$ & 요 & 80 & \\
\hline $2 \cong$ & 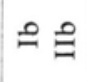 & 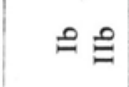 & ? & $\stackrel{2}{2}$ & \\
\hline$\approx \approx$ & $1 \stackrel{\circ}{m}$ & t 8 & 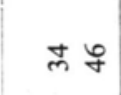 & $\stackrel{\sim}{\sim} \mathcal{F}$ & + \\
\hline$N \stackrel{\circ}{\circ}$ & $1 \stackrel{0}{+}$ & $\approx \approx$ & $\approx g$ & $\bar{n} \pi$ & 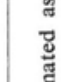 \\
\hline$\infty \cong$ & $1 \stackrel{m}{m}$ & $\overline{6}$ & $\vec{N} q$ & $\bar{m}$ & \\
\hline$\rightleftarrows 1$ & 11 & $\bar{n} 1$ & $\vec{N} 1$ & $\approx 1$ & \\
\hline ถิ & $1 \stackrel{?}{7}$ & 68 & $\bar{m} q$ & รู & \\
\hline$\cong$ & $\approx \pi$ & $\cong$ & $\stackrel{\Xi}{=}$ & $\Xi \leftrightarrows$ & \\
\hline & $\begin{array}{l}\frac{\infty}{\delta^{7}} \\
\frac{\pi}{E}\end{array}$ & 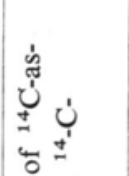 & 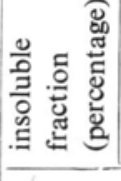 & 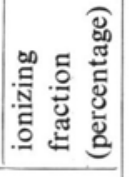 & \\
\hline 尊 & 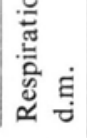 & 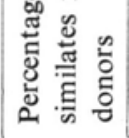 & 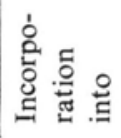 & & \\
\hline
\end{tabular}


Preshading affects also photosynthetic activity (calculated per plant) as well as its rate, calculated per leaf area, especially in sunflower. Photosynthesis calculated per dry matter, was even higher in preshaded plants than in control ones; after replacing the bean plant in NL conditions one or two days before ${ }^{14} \mathrm{CO}_{2}$-exposure, the photosynthetic rate (on a dry matter basis) become approximate to that in control ones, but in sunflower it usually exceeded the values of control plants.

The radioactivity of ${ }^{14} \mathrm{C}$-donors, after 2 -hr translocation is some indication of both the retention power of blades and/or the mobilizing forces of acceptors. As was determined in previous investigations, as well as in paper of other authors ( $\mathrm{H} \circ \mathrm{fstra}$, N elson 1969) in the course of two hours a high proportion of mobile assimilates is exported from the source.

Preshading decreased the share of radioactivity of bean plant blades (Table 2 expt. Ia), but in plants grown in NL conditions following preshading period this share increased again. In expt. IIa this share was the smallest in control plants but the differences between paricular series were small.

The rate of ${ }^{14} \mathrm{C}$-incorporation into the ethanol-insoluble fraction as well as into ionizing substances isolated by the use of ion exchanger's (Starck 1969), was much higher in sunflower than in bean plant blades (Table 2).

In blades of bean plants, preshaded immediately before ${ }^{14} \mathrm{C}_{2}$-exposure, some reduction of the relative contribution of the insoluble fraction to total redioactivity was observed, however, an increase was noted in last two series; in experiments with sunflower preshading increased ${ }^{14} \mathrm{C}$-incorporation to the insoluble fraction in blades (Table 2) and apical part (Table 3 ) in expt. Ib and slightly (statistically significant) decreased in

Table 3

General characteristic of apical part of sunflower

\begin{tabular}{|c|c|c|c|c|c|c|}
\hline $\begin{array}{c}\text { Expt. } \\
\text { No }\end{array}$ & Specification & control & $5 s(6 s)$ & $7 \mathrm{~s}$ & $\begin{array}{l}7 s+1 \mathrm{NL} \\
\quad(6 \mathrm{~s}+ \\
+2 \mathrm{NL})\end{array}$ & $\begin{array}{l}6 s+3 \mathrm{NL} \\
\quad(6 \mathrm{~s}+ \\
+4 \mathrm{NL})\end{array}$ \\
\hline $\mathrm{Ib}$ & $\begin{array}{l}\text { dry matter }(\mathrm{mg}) \\
\text { percentage of total radioactivity } \\
\text { percentage of insol. fraction }\end{array}$ & $\begin{array}{l}60 \\
15 \\
25\end{array}$ & $\begin{array}{r}24 \\
8 \\
35\end{array}$ & $\begin{array}{r}23 \\
8 \\
31\end{array}$ & $\begin{array}{r}20 \\
8 \\
39\end{array}$ & $\begin{array}{l}28 \\
12 \\
41\end{array}$ \\
\hline IIb & $\begin{array}{l}\text { dry matter }(\mathrm{mg}) \\
\text { percentage of total radioactivity } \\
\text { percentage of insol. fraction }\end{array}$ & $\begin{array}{l}150 \\
21 \\
58\end{array}$ & $\begin{array}{r}34 \\
8 \\
49\end{array}$ & $\begin{array}{l}- \\
- \\
-\end{array}$ & $\begin{array}{r}36 \\
9 \\
50\end{array}$ & $\begin{array}{l}39 \\
12 \\
53\end{array}$ \\
\hline
\end{tabular}


expt. IIb. As preliminary estimations indicate, in the ${ }^{14} \mathrm{C}$-insoluble fraction, of sunflower blades ${ }^{14} \mathrm{C}$-carbohyrates readily hydrolized (in 2 percent $\mathrm{HCl}$ on boiling water bath), contributed about $40-50$ percent of the radioactivity of insoluble franction and in the apical part even less - about 30 percent and in bean plant blades about 40-55 percent.

Sugar content, calculated per dry matter was much higher in bean plant as compared with sunflower blades. An extended period of preshading caused higher accumulation of sugars, especially in bean plant blades, which decreased in most cases if the plants were treated before ${ }^{14} \mathrm{CO}_{2}$-exposure with NL conditions. In bean plant more than in sunflower the changes in sugar content were inverse to those in relative amount of ${ }^{14} \mathrm{C}$-incorporation into the insoluble fraction.

In both species examined respiration decreased as an effect of preshading, but improved markedly (statistically significantly) after a few days of natural light following shading period.

\section{Physiological characteristic of ${ }^{14} \mathrm{C}$-acceptors}

The ${ }^{14} \mathrm{C}$-distribution pattern in the particular series of bean plant did not coincided with the organ dry matter (fig. 1). In control plants root dry matter as well as their relative share in ${ }^{14} \mathrm{C}$-translocation exceeded that of other organs in contrast to root in plants treated with extended period of shading and in plants replacing in NL conditions (differences statistically significant; Table 4, page 156).

Stem growth was reduced in a much smaller degree, and in successive experimental series their relative share of labelled compounds, exported from the blades, increased gradually and significantly. Renewed stem's growth (expressed as its dry matter), after return the plants to NL conditions for 1 or 2 days, was visible only in epxt. Ia. The proportion of ${ }^{14} \mathrm{C}$-migration to the petioles did not depend on pretreatment with various light conditions. The apical part constitutes a much smaller proportion of the plants dry matter than the stem and roots, but slightly higher than the petioles. The apical part dry matter varied slightly in plants from different light conditions in contrast to its significantly increasing share in ${ }^{14} \mathrm{C}$-transport (expt. Ia) in series exposed to ${ }^{14} \mathrm{CO}_{2}$ immediately after shading (statistically significant Table 4). This share declined again in the last series. In both experiments, the share of the apical part in total ${ }^{14} \mathrm{C}$-export from the blades calculated for its dry matter was higher than that of other acceptors, but in expt. IIa its relative share in ${ }^{14} \mathrm{C}$-translocation did not change in particular series.

In particular stem parts the relative share in labelled compounds of the total plant following in some diegree the changes in their length 

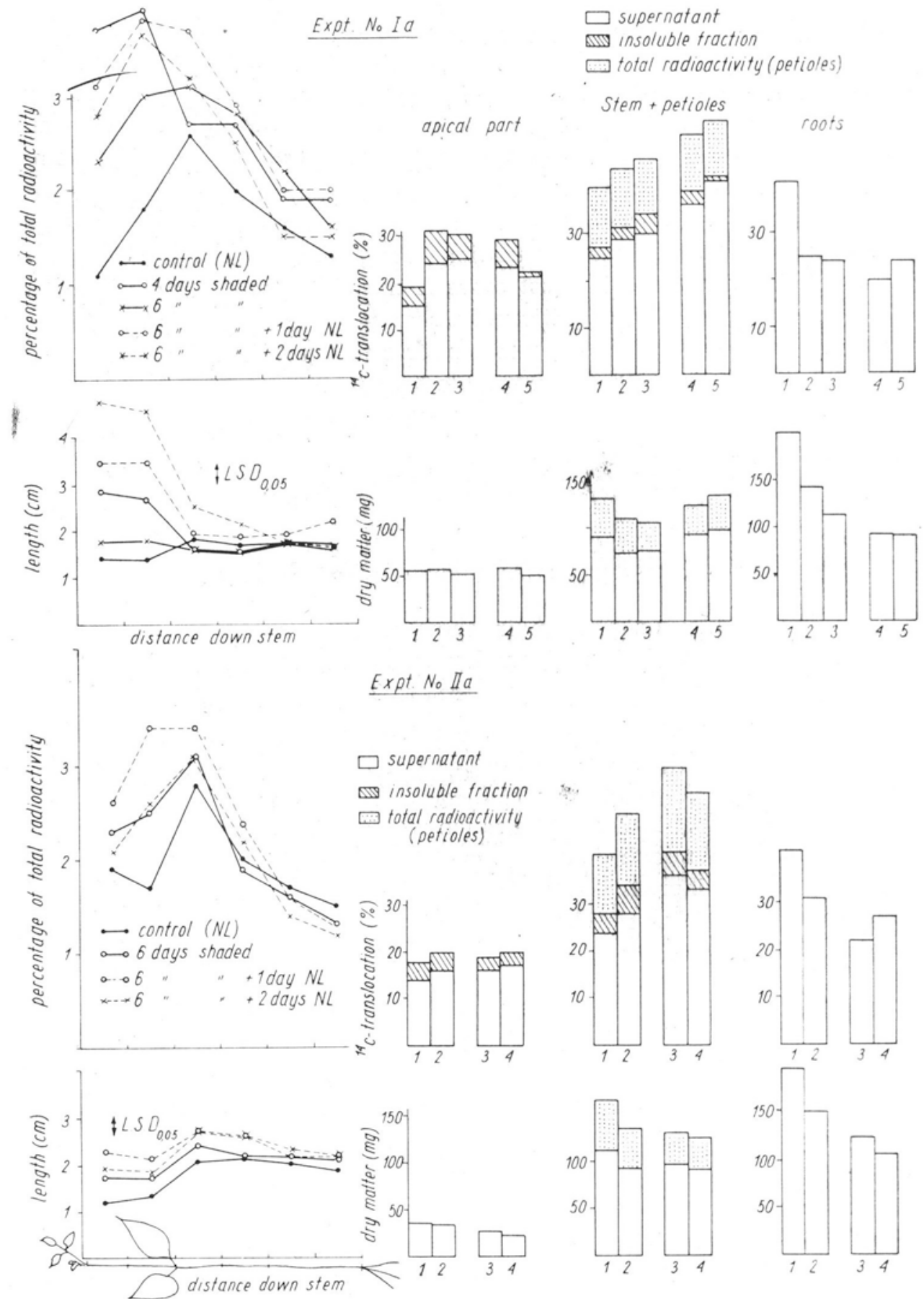

Fig. 1. Distribution of $14 \mathrm{C}$-assimilates in particular parts of bean plant stem (points on curves denote percentage of total radioactivity of the whole plant assumed as 100), share of apical part, stem, petioles and roots-in the precentage of radioactivity exported from the blades, assumed as 100 percent. Dry matter $(\mathrm{mg})$ and length of particular stem parts (cm) are also presented.

Notations of diagrams for expt. Ia and IIa: 1) - control, 2) 4 days shaded, 3) 6 days shaded, 4) 6 days shaded +1 day NL, 5) 6 days shaded +2 days NL. 

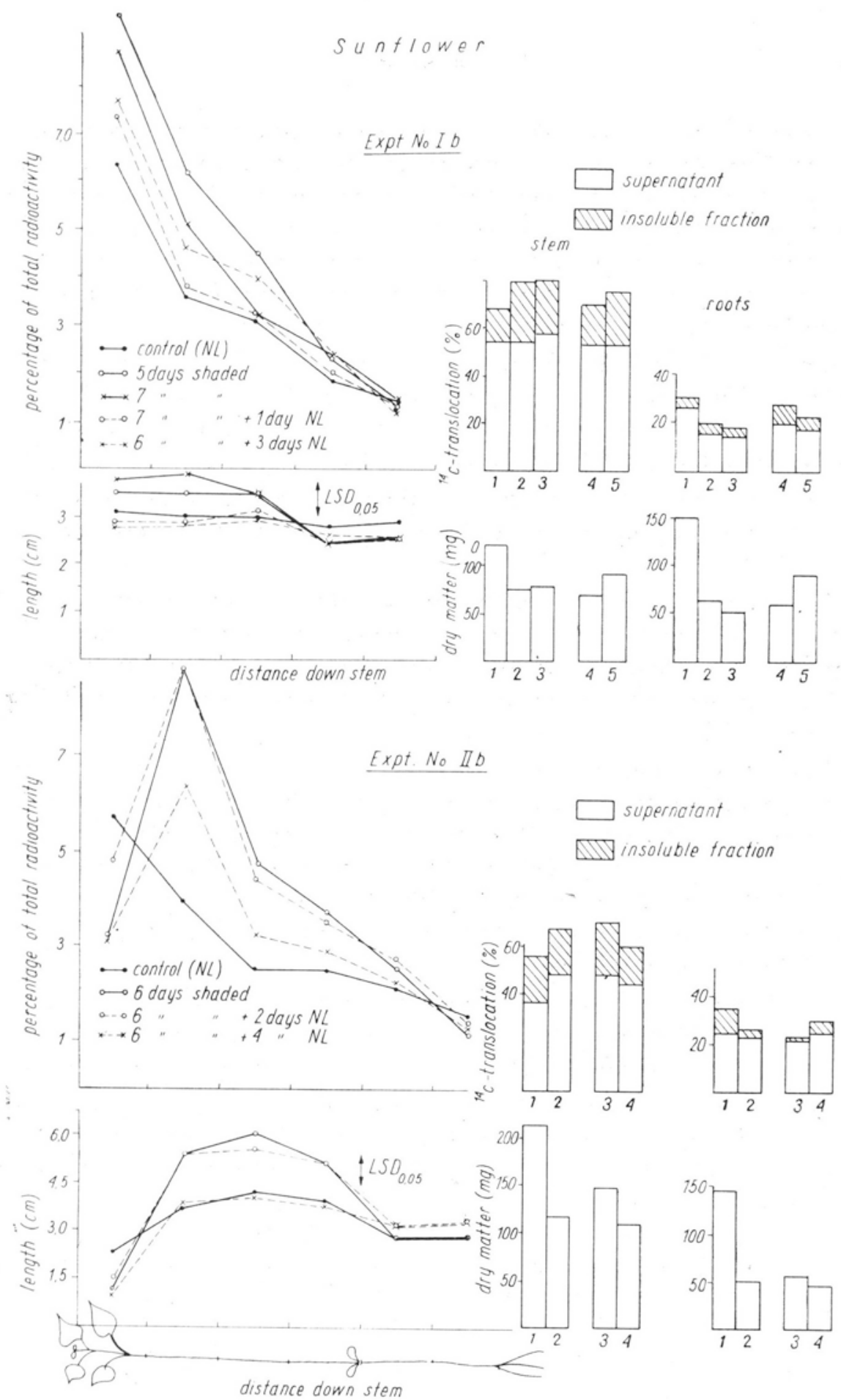

supernatant

MIV insoluble fraction
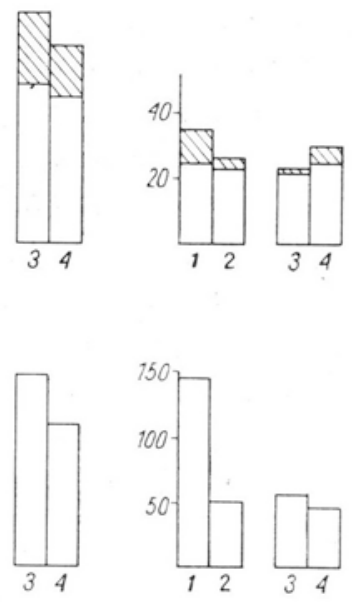

Fig. 2. Distribution of $14 \mathrm{C}$-assimilates in particular parts of sunflower stem (points on curves denote percentage of total radioactivity of the whole plant assumed as 100), share of the stem and roots in radioactivity exported from the $14 \mathrm{C}$-donors assumed as 100 percent. Dry matter $(\mathrm{mg})$ and length of particular stem parts $(\mathrm{cm})$ are also presented. Notations in succesive diagrams: in expt. Ib; 1) control, 2) 5 days shaded, 3) 7 days shaded, 4) 7 days shaded + 1 day NL, 5) 6 days shaded +3 days NL; in expt. IIb: 1) control, 2) 6 days shaded, 3) 6 days shaded +2 days NL, 4) 6 days shaded +4 days NL. 
but slightly on the changes in their weight (data not presented). The ${ }^{14} \mathrm{C}$-gradient (calculated as percentage of radioactivity of the whole plant) in control plants decreased both in downward and upward directions. The highest relative radioactivity was located in parts just below the primary leaves. The after-effect of preshading was most pronounced in the upper part of the stem, where much more ${ }^{14} \mathrm{C}$-assimilates migrated to much longer parts of stem segments.

The general pattern of dry matter and ${ }^{14} \mathrm{C}$-distribution in sunflower differed from that in bean plant (Fig. 2). Again preshading redured more root than stem growth but less than in the apical part (Table 3).

The decrement of ${ }^{14} \mathrm{C}$-migration to the roots was in all cases lower as compared with the reduction of their dry matter (Fig. 2). Therefore root activity, calculated per unit of their dry matter, increased in the preshaded series.

The relative amount of ${ }^{14} \mathrm{C}$ transported to the stem dominated distincly over that to roots in all series, but more in preshaded ones. Replacing the plants in NL conditions affected stem activity differently in both experiments, probably owing to different changes in their dry matter.

The ${ }^{14} \mathrm{C}$-gradient in the stem (Fig. 2) indicated that the length of the stem affects their share in the total radioactivity. In both experiments the lowest (in expt. Ib statistically significant, Table 4) proportion of labelled compounds migrated to the stem of control plants. Differences in the ${ }^{14} \mathrm{C}$-gradient between experimental series were observed not only in the youngest part, but also in the lower part of the stem, especially in expt. IIb.

The apical part (estimated with petioles of ${ }^{14} \mathrm{C}$-blades) in control plants contained about 15-20 percent of total radioactivity of the whole plant (Table 3); that is almost as much as the contribution of the stem.

Low light intensity, prior to ${ }^{14} \mathrm{CO}_{2}$ exposure, reduced drastically not only the apical part growth, but also its share in the total ${ }^{14} \mathrm{C}$ radioactivity. This share increased as early as after 3 or 4 days of NL pretreatment, followed shading period. In expt. Ib an increase of their dry matter was also observed (expt. Ib). The above described changes in photosynthates allocation to the particular acceptors of assimilates in plants grown in various light conditions, affected the competitions for assimilates between acceptors.

The changes in the pattern of distribution of ${ }^{14} \mathrm{C}$-assimilates produced recently under NL conditions as an aftereffect of various light conditions before ${ }^{14} \mathrm{CO}_{2}$ exposure, give some information on the interrelation between organs active as sinks of assimilates.

The curves presenting the changes in the ratio of the apical part dry matter to stem dry matter and the ratio of their shares in the total 


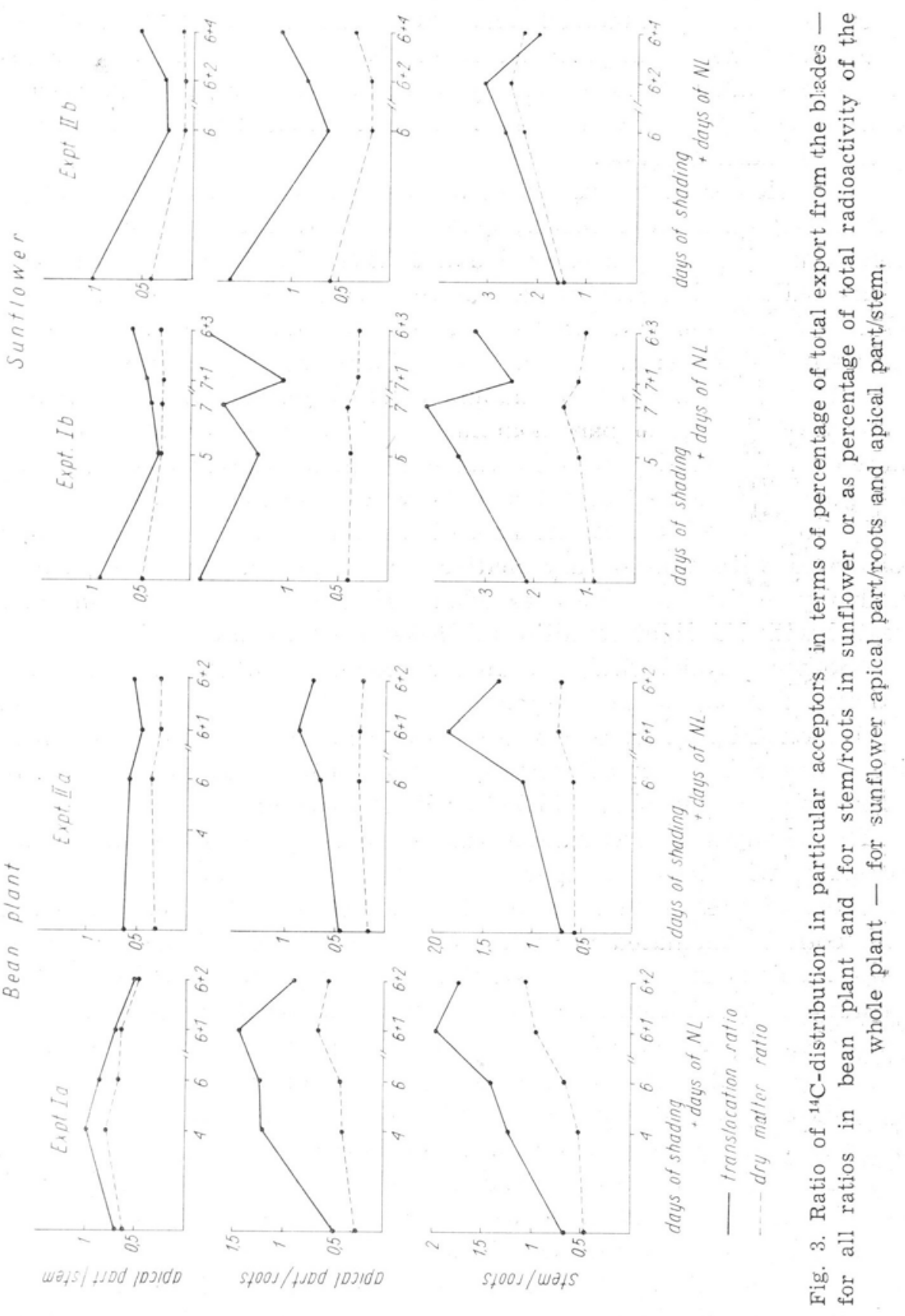


${ }^{14} \mathrm{C}$-migration in both experiments with bean plants are almost parallel and run close to each other (Fig. 3).

Some more pronounced changes between the two curves were observed in the apical part/root ratio. The translocation ratio increased in the preshaded series (especially in expt. Ia), owing to higher activity of the apical part, and decreased in plants treated with NL conditions after the shading period.

In sunflower the translocation ratios: apical part/roots and apical part/stem (expressed as percentage of total radioactivity instead of total translocation) decreased after 5 and 6 days of shading in both experiments without distinct changes in the dry matter ratio (expt. Ib) or with changes similar to those represent by the curve presented ratio of translocation (Fig. 3 expt. IIb). Therefore the competitions for assimilates in both species examined are different. In bean plant the activity of the apical part dominated over that of the stem and even more over that of the roots but not so in the sunflower seedlings, where a higher reduction of apical part growth was observed.

In both species the translocation ratio stem/roots was slightly correlated with that of dry matter. The translocation ratio increased gradually in the succesive preshaded series, but decreased in the plants treated with NL light conditions following the shading period.

Another physiological parameter examined which determines the activity of roots as an acceptor seems to be the rate of their dark respiration (Fig. 4). In both species, the relative rate of oxygen absorption decreased as an aftereffect of preshading, but mostly improved after replacing the plants in better light conditions.

The changes in respiration rate of bean plant roots, were closer correlated with those in sugar content than in sunflower.

Roots of preshaded bean plants absorbed less ${ }^{32} \mathrm{P}$ than the control ones both if calculated per plant (data not presented) or per root dry matter. This is in contrast to sunflower. Absorption of ${ }^{32} \mathrm{P}$ by sunflower seedlings from limited light conditions calculated per $1 \mathrm{~g}$ of roots dry matter, exceeded that of control plants (Fig. 4).

In series with plants replaced in NL conditions, the relative ${ }^{32} \mathrm{P}$ absorption by $1 \mathrm{~g}$ of dry matter of bean plant roots increased gradually to the level of the control series. In sunflower the highest ${ }^{32} \mathrm{P}$ absorption was observed in 7 days preshaded plants or in the $6 \mathrm{~s}+2 \mathrm{NL}$ series. Some positive correlation between ${ }^{32} \mathrm{P}$-absorption and ${ }^{32} \mathrm{P}$-migration to the aerial parts was observed in sunflower. In bean plant the lowest proportion of ${ }^{32} \mathrm{P}$ was transported out of the roots in control plants. In bean plant, ${ }^{32} \mathrm{P}$-absorption rate by $1 \mathrm{~g}$ of root dry matter in particular series (expressed in relative values as percentage of control series) seems to be correlated with dark respiration rate and sugar content, but it was not so in sunflower. 

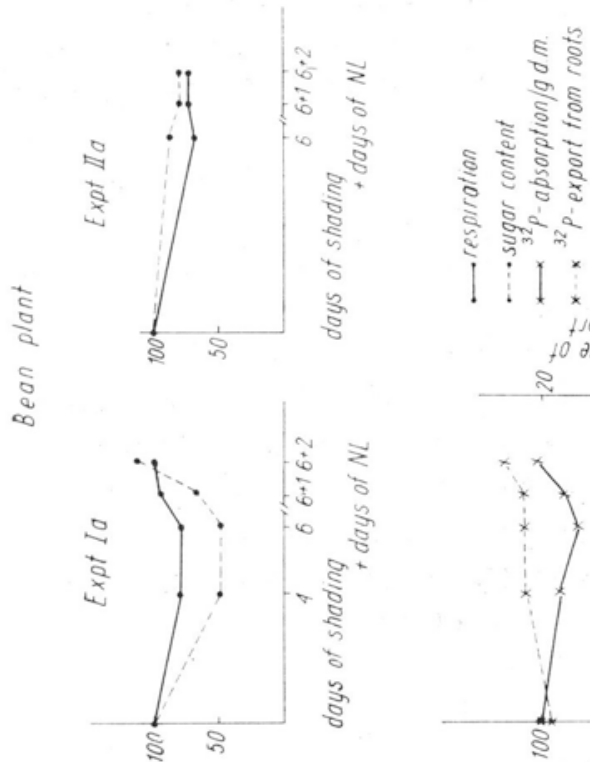

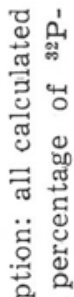

落

$1,00 x a-d z \varepsilon$
10 abojuajjad

2 ?

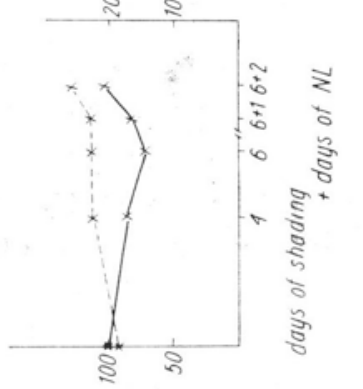

में क्ष

赔

:

ठั

कี

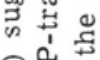

用

क्षे

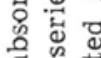
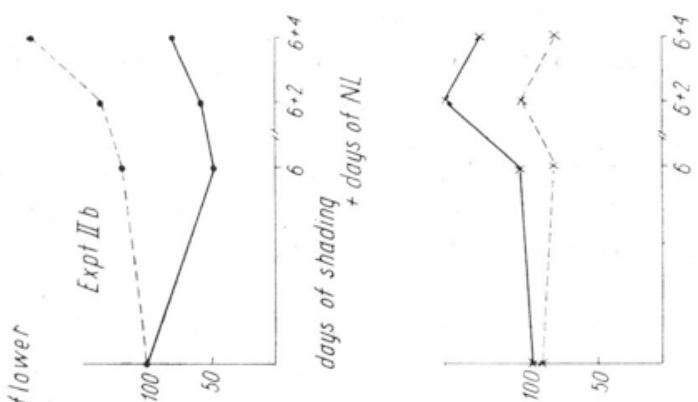

का

者

\&

कृष

$\exists \circ$ 荞

\%

๘

है ฮูँ

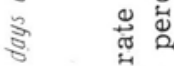

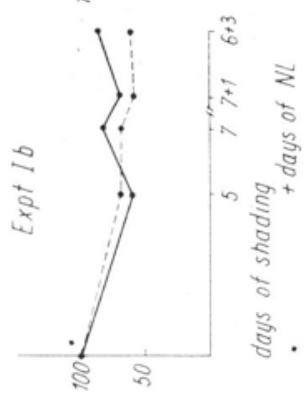

10s/u0s yo abofuas sad

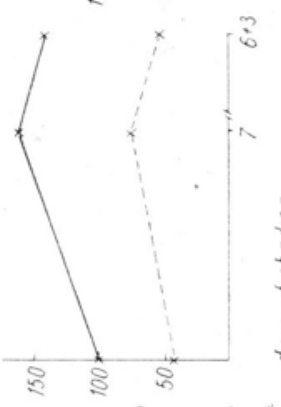

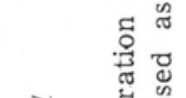

$₹ \quad .4$ के

¿

다

究

菅

मf

+ $\stackrel{\text { b }}{-1}$

103,

$d_{z \varepsilon}$ vold djosqD

$\infty_{\dot{1}}^{\infty}$ 
Metabolic changes of ${ }^{14} \mathrm{C}$-assimilates in acceptors

The rate of incorporation of ${ }^{14} \mathrm{C}$-assimilates into particular fractions was usually higher in sunflower than in bean plant in the comparable stage of development (Tables 2, 3, 5, Figs. 1, 2), but it varied in both experiments.

In bean plant stem the radioactivity of the soluble fraction constituted about $85-94$ percent in control plants.

Pretreatment with different light conditions did not significantly influence the rate of ${ }^{14} \mathrm{C}$-substances incorporation into the ethanol-insoluble fraction in that organ (Fig. 1).

In the stem very few or no assimilates were included into the ionizing fraction in both experiments. Sugar content increased as a consequence of preshading. The highest sugar specific radioactivity was observed in 4-6 days preshaded plants (expt. Ia), and it decreased in the last two series. In expt. IIa in all series the degree of sugar ${ }^{14} \mathrm{C}$-labelling was mostly the same (Table 5).

Table 4

Average percentage of ${ }^{14} \mathrm{C}$-transport, converted according to Bliss table

\begin{tabular}{|c|c|c|c|c|c|c|c|c|}
\hline \multirow{2}{*}{ Species } & \multirow{2}{*}{$\begin{array}{c}\text { Expt. } \\
\text { No }\end{array}$} & \multirow{2}{*}{$\begin{array}{c}\text { Plant } \\
\text { organs }\end{array}$} & \multicolumn{5}{|c|}{ Experimental series } & \multirow{2}{*}{$\begin{array}{l}\text { LSD } \\
0,05\end{array}$} \\
\hline & & & control & $4 s$ & $6 s$ & $6 s+1 N L$ & $6 s+2 N L$ & \\
\hline \multirow{7}{*}{$\begin{array}{l}\text { Bean } \\
\text { plant }\end{array}$} & \multirow[t]{4}{*}{ Ia } & apical & & & & & & \\
\hline & & part & 26.2 & 34.4 & 33.1 & 32.3 & 28.1 & 2.8 \\
\hline & & stem & 30.9 & 33.4 & 35.9 & 38.6 & 40.5 & 2.8 \\
\hline & & roots & 40.0 & 30.0 & 29.5 & 26.7 & 28.9 & 2.8 \\
\hline & \multirow[t]{3}{*}{ IIa } & $\begin{array}{l}\text { apical } \\
\text { part }\end{array}$ & 25.3 & - & 26.8 & 25.9 & 26.2 & 4.5 \\
\hline & & stem & 32.0 & - & 35.7 & 40.1 & 37.8 & 5.5 \\
\hline & & roots & 39.9 & - & 33.9 & 27.5 & 31.2 & 4.5 \\
\hline \multirow{6}{*}{$\begin{array}{l}\text { Sunflo- } \\
\text { wer }\end{array}$} & \multirow{4}{*}{$\mathrm{Ib}$} & & control & $5 \mathrm{~s}(6 \mathrm{~s})$ & $7 \mathrm{~s}$ & $7 \mathrm{~s}+1 \mathrm{NL}$ & $6 s+3 N L$ & LSD \\
\hline & & & & & & $(6 s+2 N L)$ & $(6 s+4 N L)$ & 0,05 \\
\hline & & stem & 54.8 & 62.7 & 63.5 & 56.9 & 60.0 & 4.8 \\
\hline & & roots & 35.0 & 26.4 & 25.6 & 31.7 & 28.9 & 4.6 \\
\hline & \multirow[t]{2}{*}{$\mathrm{IIb}$} & stem & 49.0 & 55.4 & - & 56.7 & 52.0 & 6.8 \\
\hline & & roots & 36.1 & 30.4 & - & 28.8 & 32.6 & 6.7 \\
\hline
\end{tabular}

*) figures in brackets - series in expt. No IIb notations - like in Table 2

In sunflower the proportion of the soluble fraction in total radioactivity of the stem was 83 and 65 percent in expts Ib and IIb respectively (Fig. 2); preshading increased ${ }^{14} \mathrm{C}$-incorporation into the insoluble fraction in experiment Ib without significant effect in expt. IIb. The relatively high proportion of ${ }^{14} \mathrm{C}$-incorporation into the insoluble fraction (about 30 percent of total radioactivity) of the stem in all series of 
preshaded sunflower, might be caused by intensive growth of that organ. After replacing the plants in better light conditions a few days before ${ }^{14} \mathrm{CO}_{2}$ exposure, almost the same proportion of ${ }^{14} \mathrm{C}$ was incorporated into the ethanol-insoluble substances. The supposition that in sunflower's stem incorporation of ${ }^{14} \mathrm{C}$ into the insoluble fraction is dependent on its growth supported indirectly by preliminary estimations of the contribution of ${ }^{14} \mathrm{C}$-carbohydrates (except cellulose) in the insoluble fraction. ${ }^{14} \mathrm{C}$-carbohydrates constitute in that fraction only about $30-36$ percent and their specific radioactivity was $4-5$ times lower than that in blades and apical part (unpublished data). It means that $64-70$ percent of the ${ }^{14} \mathrm{C}$-insoluble fraction may be incorporated into some constitutive substances.

In the stem of sunflower the rate of ${ }^{14} \mathrm{C}$ incorporation into the ionizing fraction varied in both experiments within the limits of 10 30 percent (data not presented).

In apical part of the bean plants the insoluble fraction of control plants in both experiments constituted slightly above 20 percent and significantly changed in the other series (Fig. 1). In expt. Ia the lowest sugars content and their specific radioactivity was detected in the control plants. In the expt. IIa sugar content did not change in the preshaded series, but specific radioacitivity of sugars was also lowest in the control plants (Table 5).

A different pattern was observed in the sunflower apical part, where ${ }^{14} \mathrm{C}$ incorporation into the insoluble fraction was relatively high, (Table 3) especially in expt. IIb. In expt. Ib the rate of ${ }^{14} \mathrm{C}$-incorporation into the ethanol-insoluble fraction was the lowest in apical part of the control plant and increased in the succesive series (Table 3). It correlated in control plants with their highest sugar content and specific radioactivity (Table 5). Preshading influenced less metabolic changes of ${ }^{14} \mathrm{C}$ in the apical part, in expt. IIb, where the degree of ${ }^{14} \mathrm{C}$-incorporation into the insoluble fraction was much higher and more. stable in all series examined (Table 3 ).

In bean plant roots almost all ${ }^{14} \mathrm{C}$ was in the soluble fraction (Fig. 1) but in sunflower roots the insoluble fraction of control plants constituted $20-30$ percent of their radioactivity; it varied however in particular series of both experiments (Fig. 2).

In roots of both species some relation between the degree of ${ }^{14} \mathrm{C}$-incorporation into ionizing substances and the specific activity of sugars was observed. The specific radioactivity of sugars increased particularly in expt. Ia as the shading period was extended and decreased after replacing the plants in NL conditions before ${ }^{14} \mathrm{CO}_{2}$ exposure. These changes seem to be negatively correlated with those in sugar content (Fig. 4) and the ${ }^{14} \mathrm{C}$-incorporation into the ionizing fraction, which in bean plant roots was rather low (Table 5). 


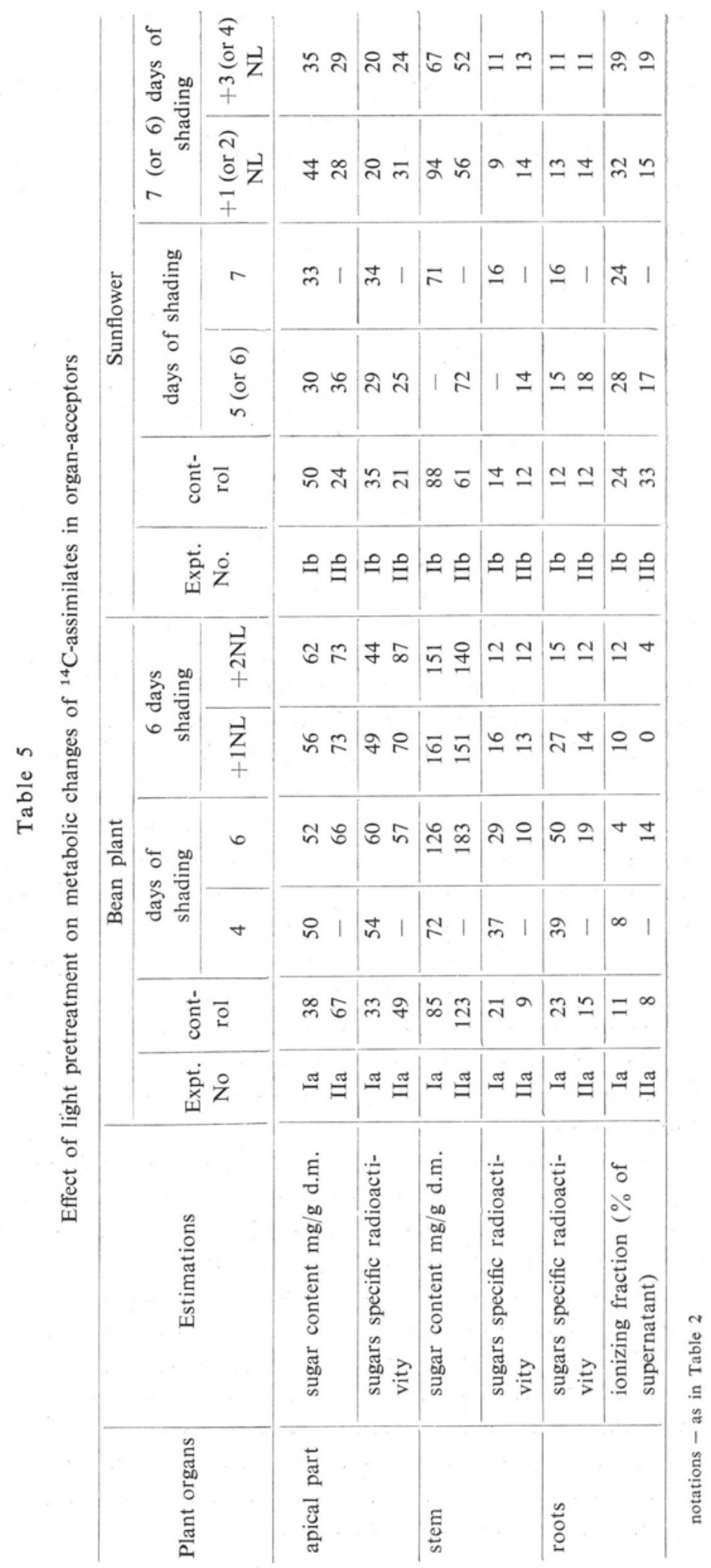




\section{DISCUSSION}

Interaction between donor-acceptor organs seems to depend, in a very complex manner on photosynthesis as wall as growth and other processes (Crafts, 1970; D avidson, 1966; J esk o, 1971, 1972; Milthorpe et al. 1969; Neales et al. 1968).

In the reported experiments plants with temporarily limited supply of assimilates by preshading and those after improvement of light conditions were examined.

There was no close relationship between photosynthesis and export of ${ }^{14} \mathrm{C}$-assimilates from the leaves. Total ${ }^{14} \mathrm{C}$-migration out of the blades seems to depend on the retention of assimilates in donors (roughly estimated on the basis of the amount of ${ }^{14} \mathrm{C}$ incorporated into the ethanol-insoluble fraction, especially into constitutive cell material), and/or activity of acceptors, which may exert some pull forces.

Only in one experiments with bean plant (Ia) some relation between the decrease of ${ }^{14} \mathrm{C}$-incorporation into the ethanol-insoluble fraction and the increase of ${ }^{14} \mathrm{C}$-export form the blades was observed. In that experiment a relatively high activity of apical part seems to promote migration out of ${ }^{14} \mathrm{C}$-dionors.

In sunflower as a rule, the degree of ${ }^{14} \mathrm{C}$-incorporation into the insoluble fraction was much higher than in bean plant; nevertheless ${ }^{14} \mathrm{C}$-export from sunflower blades was relatively rapid (S t a r c k, 1964, 1971; Hofstra, 1969). In blades of both species $2 \mathrm{hrs}$ after ${ }^{14} \mathrm{CO}_{2}$ exposure less than half of the radioactivity of the insoluble fraction was present in the polysacharides, probably mainly starch (unpublished data). To know the relationship between assimilates retention in donors and the rate of their migration to acceptors more detailed studies are necessary.

In plants grown temporarily under low light conditions, particular organ-acceptors competed for the limited supply of assimilates. This competition depends slightly on the size of the organs.

When comparing the changes in the ratio of acceptor share in ${ }^{14} \mathrm{C}$ exported from the blades depending on light pretreatment the supposition may be advanced, that in shaded bean plants a competition for assimilates exists between stem and roots and in some cases between apical part and roots. The migration of ${ }^{14} \mathrm{C}$ to the apical part and stem occured at the cost of roots (S t a r c k 1969). Petioles seem to play little or no part in controlling translocation.

In sunflower, competition between stem and roots is also very strong, but the most pronounced cessation of growth as well as decrease in the share in the plants radioactivity were observed in the apical part and then in the roots (see also Starck 1971). 
${ }^{14} \mathrm{C}$-incorporation into the insoluble fraction, seems to affect competition for assimilates and as a consequence - the pattern of their distribution. Köchler and Leonard (1971) observed, that in petioles of detached leaves a relatively higher amount of ${ }^{14} \mathrm{C}$ was incorporated into insoluble fraction as compared with that in attached leaves, which exported assimilates to other organs. In sunflower stem, a large proportion of ${ }^{14} \mathrm{C}$ was found in the insoluble fraction ( $\mathrm{S} \mathrm{ta} \mathrm{r} \mathrm{ck}$ 1971, W ittle 1970). The relatively higher rate of ${ }^{14} \mathrm{C}$-incorporation as an aftereffect of shading (expt. Ib and Starck 1971b) may cause enhancement of competition between stem and roots. Lateral ${ }^{14} \mathrm{C}$-transport causing accumulation of ${ }^{14} \mathrm{C}$ in the stem tissues outside the conducting bundles, decreased the amount of mobile ${ }^{14} \mathrm{C}$-substances. Very important seems to be the chemical composition of the insoluble fraction. As preliminary estimation indicates (unpublished data) in the stem ${ }^{14} \mathrm{C}$-polysacharides (except cellulose), constituted about $30-50$ percent of ${ }^{14} \mathrm{C}$-insoluble fraction with rather low specific radioactivity, especially in control plants; in preshaded ones, the content of carbohydrates decreased from 9 to $5 \mathrm{mg} / \mathrm{g}$ fresh weight what suggests the possibility of remobilization of carbohydrates (probably starch), accumulated temporarily in the stem of plants after treatment with conditions limiting the supply of assimilates.

Disturbance of the natural donor-acceptor balance by temporarily shading of the plants affected also root dark respiration owing to changes in the current rate of photosynthesis, as was reported by N e a les (1966), Osman (1971). Respiration recovered a few days after replacing the bean plants in natural light conditions and was associated with an increase in sugar content, in contrast to sunflower (see also $\mathrm{S}$ ta r ck, in press).

Neither was any correlation between sugar content and respiration rate reported by Porter and Bird (1962, cit. from Neales 1966). The other process, indicating the physiological activity of roots - the rate of ${ }^{32} \mathrm{P}$ absorption, calculated per root dry matter, in bean plant followed similar course as the changes in respiration rate and sugar content: it decreased in the preshaded series and improved in series replaced in NL conditions.

Absorption of ${ }^{32} \mathrm{P}$, calculated per root dry matter, in the preshaded series of sunflower, exceeded that in control plants and slightly decreased in the plants replaced in NL conditions a few days before ${ }^{14} \mathrm{CO}_{2}$ exposure. Similarly ${ }^{32} \mathrm{P}$-transport to the aerial parts seemed to follow ${ }^{32} \mathrm{P}$-absorption. Nevertheless ${ }^{32} \mathrm{P}$-absorption calculated per plant was in both species, in all preshaded series lower than that in control plants. Davidson (1966) also observed decrease in ${ }^{32} \mathrm{P}$-absorption by the roots of Dactylis glomerata in plants with sligthly resticted 
assimilates supply as the result of defoliation, but absorption rapidly returned to the pre-treatment rate.

R a czyński (1955) reported various effects of light intensity on ${ }^{32} \mathrm{P}$-absorption depending on the developmental stage of wheat but Krastina and Pal (1962) observed a decreasing absorption of several mineral substances (calculated per plant basis), due to treatment of maize plants $12 \mathrm{hrs}$ before and during absorption with lower light intensity.

The relatively higher ${ }^{32} \mathrm{P}$-absorption by sunflower roots of prehaded plants, may be caused by a high demand for $\mathrm{P}$ in the aerial parts, especially blades, in plants immediately after the shading period; this may be caused by a reatively high aerial parts to roots ratio in plants treated temporarily with suboptimal light conditions (see $\mathrm{Starck}$ in press). This ratio increased form 3,3 and 4,5 in NL series to 4,1 and 5,9 in the preshaded ones. The relative amount of ${ }^{32} \mathrm{P}$-absorption by bean plant roots was not related with the values of aerial parts/root dry matter ratio.

In conclusion of the discussion, concerning some preliminary observations on the relationships between sink and sources, it should be underlined, that the above mentioned suppositions are based only on the coincidence between some changes in the rate of particular processes; the causal interrelationships will be examined in more detail in the future.

\section{Acknowledgements}

This work was coordinated and partially supported by Polish Academy of Science (Problem No 09. 1.7).

Author wish to express thanks to Miss T. B a r a mow for technical assistance.

\section{REFERENCES}

Brauer R., De Wit C. T., in: Root Growth, 1970, Butterworth, 224-244.

Crafts A. S., Cris p C. E., Phloem transport in plants, 1971.

W. H. Freeman and Co. San Francisco.

Davidson L. J., Milthorpe F. L., 1966, Ann. Bot. 30: 185-198.

Geiger D. R., 1966, Plant Physiol. 41: 1667-1672.

Geiger D. R., Christy A. L., 1971, Plant Physiol. 47: 172-174.

Hof stra G., Ne ls on C. D., 1969, Planta 88: 103-112.

Jesko T. et al., 1971, Photosynthetica 5: 233-240.

J e sko T., 1972, Photosynthetica, 6: 51-56.

Kra stina E. E., Pal J., 1962, Dokł. TSChA, 79: 107-113.

Kocher H., Leonard O. A., 1971, Pl. Physiol. 47: 212-216.

Milthorpe F. L., Moorby J., 1969, Ann. Rev. Pl. Ph., 20: 117-138.

Neales T. F., D a vi es J. A., 1966, Austr. J. Biol. Sci. 19: 471-480. 
Neales T. F., Incol1 L. D., 1968: Bot. Rev. 34: 107-125.

Osman A. M., 1971, Photosynthetica, 5: 107-112.

R a c zyński W. W., 1955, Izw. Tim. S. Ch. A., 2: 193-210.

Shir o y a M., 1968, Plant Physiol. 43: 1605-1610.

S t ar c k Z., 1964, Acta Soc. Bot. Pol. 33: 759-771.

Sta r ck Z., 1969, Acta Soc. Bot. Pol. 37: 583-600.

St a c k Z., 1971, ibid. 39: 653-667.

Starck Z., Symp. Structure and function of primary root tissues, in press. Wh it tle C. M., 1970, Planta, 95: 247-263.

\section{Wstęne badania dotyczące interakcji pomiędzy niektórymi procesami fizjologicznymi donorów i akceptorów asymilatów}

\section{Streszczenie}

Badania prowadzono na roślinach fasoli i słonecznika rosnących w kulturach wodnych, w warunkach zróżnicowanego oświetlenia, modyfikującego między innymi aktywność fotosyntetyczną. Rośliny ocieniano w ciągu $4-7$ dni $(50 \%$ naturalnego natężenia światła) bezpośrednio przed pomiarem fotosyntezy i transportu ${ }^{14} \mathrm{C}$-asymilatów lub też po okresie ocienienia rośliny przenoszono do warunków naturalnego oświetlenia (NL) na 1-4 dni przed ekspozycją w atmosferze znakowanej ${ }^{14} \mathrm{CO}_{2}$.

Przedłużający się okres zacienienia hamował wzrost roślin szczególnie korzeni i redukował aktywność fotosyntezy, (mierzoną na podstawie asymilacji ${ }^{14} \mathrm{CO}_{2}$ ) co szczególnie wyraźnie zaznaczyło się u słonecznika.

Transport ${ }^{14} \mathrm{C}$-asymilatów oznaczano na podstawie radioaktywności poszczególnych organów, 2 godz. po ekspozycji roślin w atmosferze znakowanej ${ }^{14} \mathrm{CO}_{2} \mathrm{i}$ wyrażono w \% radioaktywności ogólnej całej rośliny. Po kilkudniowym ocienieniu roślin znakowane asymilaty przemieszczały się do korzeni w mniejszym stopniu niż u roślin kontrolnych natomiast $w$ większym stopniu - do łodygi. Po przeniesieniu uprzednio ocienionych roślin na kilka dni do warunków NL na ogół nie obserwowano istotnych zmian $\mathrm{w}$ dystrybucji ${ }^{14} \mathrm{C}$-asymilatów.

W blaszkach i korzeniach roślin ocienianych intensywność oddychania w ciemności była znacznie mniejsza w porównaniu z roślinami z warunków naturalnego oświetlenia; po przeniesieniu roślin na kilka dni do warunków NL intensywność oddychania mierzona w ciemności istotnie wzrastała.

U fasoli rosnącej okresowo w zróżnicowanych warunkach oświetlenia zaobserwowano zbliżony przebieg zmian intensywności: oddychania, zawartości cukrów w korzeniach i absorpcji ${ }^{32} \mathrm{P}$, czego nie stwierdzono u słonecznika, u którego absorpcja ${ }^{32} \mathrm{P}$, przeliczona na $1 \mathrm{~g}$ suchej masy korzeni, u roślin uprzednio ocienianych, przewyższała absorpcję u roślin kontrolnych. 